Article

\title{
Bioenergy from Periodically Waterlogged Cropland in Europe: A First Assessment of the Potential of Five Perennial Energy Crops to Provide Biomass and Their Interactions with Soil
}

\author{
Thorsten Ruf *, Varentta Audu, Katja Holzhauser and Christoph Emmerling \\ Faculty of Regional and Environmental Sciences, Department of Soil Science, Campus II, University of Trier, \\ D-54286 Trier, Germany \\ * Correspondence: ruf@uni-trier.de; Tel.: +49-651-201-2581
}

Received: 29 May 2019; Accepted: 10 July 2019; Published: 12 July 2019

check for updates

\begin{abstract}
Harvesting of silage maize in late autumn on waterlogged soils may result in several ecological problems such as soil compaction and may subsequently be a major threat to soil fertility in Europe. It was hypothesized that perennial energy crops might reduce the vulnerability for soil compaction through earlier harvest dates and improved soil stability. However, the performance of such crops to be grown on soil that are periodically waterlogged and implications for soil chemical and microbial properties are currently an open issue. Within the framework of a two-year pot experiment we investigated the potential of the cup plant (Silphium perfoliatum L.), Jerusalem artichoke (Helianthus tuberosus), giant knotweed (Fallopia japonicum $\times$ bohemica), tall wheatgrass (Agropyron elongatum), and reed canary grass (Phalaris arundinacea) for cultivation under periodically waterlogged soil conditions during the winter half year and implications for soil chemical and biological properties. Examined perennial energy crops coped with periodical waterlogging and showed yields $50 \%$ to $150 \%$ higher than in the control which was never faced with waterlogging. Root formation was similar in waterlogged and non-waterlogged soil layers. Soil chemical and microbial properties clearly responded to different soil moisture treatments. For example, dehydrogenase activity was two to four times higher in the periodically waterlogged treatment compared to the control. Despite waterlogging, aerobic microbial activity was significantly elevated indicating morphological and metabolic adaptation of the perennial crops to withstand waterlogged conditions. Thus, our results reveal first evidence of a site-adapted biomass production on periodical waterlogged soils through the cultivation of perennial energy crops and for intense plant microbe interactions.
\end{abstract}

Keywords: plant adaptation mechanisms; soil microbial activity; soil microbial biomass; Stagnosols; waterlogging

\section{Introduction}

In the past decade, the cultivation of bioenergy crops on arable land, particularly for methanation purposes, has increased. Its aim is to substitute fossil fuels and to produce energy less damaging to the environment [1,2]. Typically, anaerobic digestion in agricultural biogas plants is done using a mixture of animal excrements and bioenergy crops that are specifically cultivated for methanation. The suitability of a wide range of crops for anaerobic digestion was tested in numerous studies [3-8]. Among these bioenergy crops, silage maize (Zea mays) is the most economically important crop under European temperate conditions since it combines high biomass yields of about 10 to $20 \mathrm{Mg}$ dry weight ha ${ }^{-1}$ and a high biochemical methane potential (BMP) in a range of 280 to $340 \mathrm{~L}_{\mathrm{N}} \mathrm{CH}_{4} \mathrm{~kg}^{-1}$ volatile substance (VS) $[3,5,6]$. 
Recently, perennial energy crops (PECs) have been introduced as promising alternatives for biomass production. They are likely to enhance agrobiodiversity, may reduce soil surface runoff and vulnerability for soil erosion, presumably improve groundwater quality and were proven to sequester carbon in soil [9-15]. However, in terms of methane yields per hectare they cannot entirely compete with silage maize. For instance, the cup plant (Silphium perfoliatum L.) and tall wheatgrass (Agropyron elongatum, 'Szarvasi-1') typically showed BMPs approx. 20\% to $30 \%$ lower than that of maize at comparable biomass yields $[4,16]$.

One major concern of maize cultivation in temperate regions (e.g., Europe) is the potential risk of soil erosion and soil compaction [13]. There is much evidence that soil compaction during silage maize cultivation may frequently appear for soils showing periodic water stagnation (e.g., Stagnosols and Planosols that make up approximately $10 \%$ of the agricultural land in Germany). Specifically, these soils tend to show waterlogged conditions during late autumn and winter which corresponds with silage maize harvesting under European conditions (mid-October to early November), resulting in a pronounced soil compaction. In general, events of soil compaction and severe soil damages under maize cultivation potentially result from an unfavorable combination of pedogenic factors, prevailing weather and soil moisture conditions as well as crop-specific management efforts [17]. From the perspective of soil protection, abundant autumn precipitation prior to the harvest period of silage maize and the severely limited drainage, make these soil types the least favorable sites for maize cultivation.

Thus, it is hypothesized that site-adapted cultivation of certain PECs would have the potential to distinctly reduce vulnerability of soil compaction by combining earlier harvest dates in late summer with typically lower soil moisture contents and enhanced soil stabilization due to the permanent rooting system and absence of tillage [18]. However, the general suitability and performance of PECs for cultivation on soils that show periodically waterlogged conditions during the winter season and generally dry conditions during summer are largely unknown, except for reed canary grass (Phalaris arundinacea) $[19,20]$. According to Evans and Jackson et al., outliving periods of waterlogged conditions, accompanied with oxygen limitation and low redox potential, requires specific morphological and biochemical adaptation mechanisms [21,22]. For example, reduced stomatal conductance under hypoxic conditions can be considered as a mechanism to avoid self-poisoning by plant-toxic fermentation products and cytoplasmic acidosis of root cells, however, at the expense of slower growth rates [22]. More sophisticated morphological adaptation mechanisms such as the formation of aerenchyma tissue aim to avoid oxygen starvation and to sustain aerobic energy metabolism of root cells [22-24]. It is likely that such adaptation mechanisms may imply changes in soil biochemical processes.

With the present study, we investigated the suitability of PECs for cultivation on Stagnosols—soils exhibiting periodically waterlogged conditions during the winter half year and rather dry conditions during summertime-and their effects on the chemical and biological properties of soil. Therefore, we conducted a two-year pot experiment which allowed for precise soil water adjustment, using five promising PECs (grasses and forbs) each under two soil moisture treatments. We determined plant parameters like shoot and root biomass development as well as their interactions with soil. For this, parameters such as $\mathrm{pH}$ value, soil organic carbon as well as soil microbial biomass and activity were measured.

\section{Materials and Methods}

The experiment was conducted in the western part of Germany, close to the border of Luxembourg at an altitude of about $265 \mathrm{~m}$ above sea level (m.a.s.l). According to the climate classification scheme of Köppen and Geiger, the climate of the study site is classified as warm summer oceanic climate (Cfb) [25].

\subsection{Experimental Setup}

For the experiment, 50 Kick-Brauckmann plant culture pots with a volume of $7 \mathrm{~L}$ (Stoma Gmbh, Siegburg, Germany) were used. The pots were stepwise filled and compacted with a sandy loam taken from the topsoil of a stagnic Cambisol aiming at a bulk density of $1.25 \mathrm{~g} \mathrm{~cm}^{-3}$ (Table 1). Frequency 
domain (FD) sensors (ECH $\mathrm{E}_{2} \mathrm{O}$ EC-5, Decagon Devices, Pullman, WA, United States) for determination and observation of volumetric water contents were vertically installed at a medium depth in the pots, calibrated and connected to a data logger (Figure 1; Table 1). The logging interval was set to one hour.

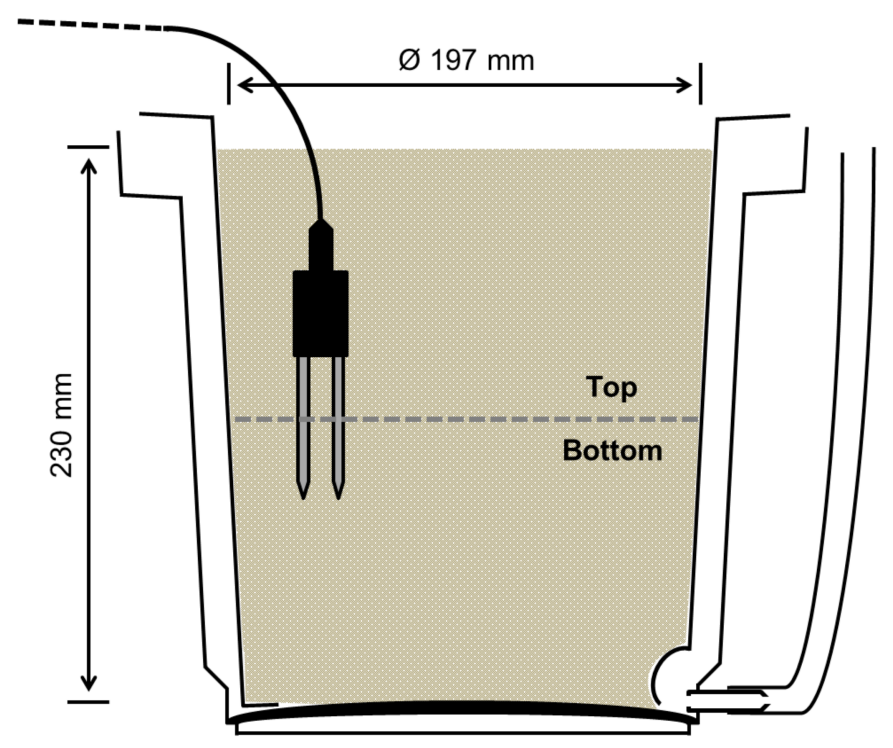

Figure 1. Scaled, schematic depiction of the Kick-Brauckmann plant culture pots with subdivision into 'Top' and 'Bottom' layers and installation position of the Frequency domain FD sensors for determination of volumetric water contents.

Table 1. Characterization of the experimental setup.

\begin{tabular}{|c|c|c|}
\hline \multicolumn{3}{|l|}{ Pots } \\
\hline Type & & Kick-Brauckmann \\
\hline Volume & $\mathrm{L}$ & 7.0 \\
\hline \multicolumn{3}{|l|}{ Soil $^{\mathrm{a}}$} \\
\hline Origin & & $\begin{array}{l}\text { Topsoil of a stagnic Cambisol developed from Devonian } \\
\text { clay and sandstones with small levels of loess; collected at } \\
49.889^{\circ} \mathrm{N}, 6.712^{\circ} \mathrm{E}\end{array}$ \\
\hline Preparation & & Sieved to $6 \mathrm{~mm}$ \\
\hline Target bulk density & $\mathrm{g} \mathrm{cm}^{-3}$ & 1.25 \\
\hline $\mathrm{pH}$ value & & 5.9 \\
\hline Soil organic carbon & $\mathrm{g} \mathrm{kg}^{-1}$ & 13.0 \\
\hline Soil nitrogen & $\mathrm{g} \mathrm{kg}^{-1}$ & 0.95 \\
\hline $\mathrm{C}$ to $\mathrm{N}$ ratio & & 13.7 \\
\hline \multicolumn{3}{|c|}{ Grain size distribution } \\
\hline Sand fraction & $\%$ & 57.8 \\
\hline Silt fraction & $\%$ & 22.7 \\
\hline Clay fraction & $\%$ & 19.4 \\
\hline \multirow{2}{*}{ Texture class } & & Ls4 (acc. to [26]) \\
\hline & & SL (acc. to [27]) \\
\hline
\end{tabular}


Table 1. Cont.

\begin{tabular}{|c|c|}
\hline \multicolumn{2}{|l|}{$\begin{array}{l}\text { Instrumentation for soil moisture } \\
\text { monitoring }\end{array}$} \\
\hline Type & $\begin{array}{l}\text { FD-sensors }\left(\mathrm{ECH}_{2} \mathrm{O} \text { EC-5, Decagon Devices, Pullman, WA, }\right. \\
\text { United States) connected to a Delta-T Data-Logger (Delta-T } \\
\text { Devices Ltd., Cambridge, Great Britain) }\end{array}$ \\
\hline Calibration & $\begin{array}{l}\text { Calibration equation for mineral soils provided by } \\
\text { Decagon Devices: } \Phi=11.9 \times 10^{-4} \times \mathrm{mV}-0.401 \text {; } \\
\text { excitation: } 2500 \mathrm{mV}\end{array}$ \\
\hline \multicolumn{2}{|l|}{ Fertilization } \\
\hline Type & $\begin{array}{l}\text { 'Vollkorndünger Perfekt' (Raiffeisen GmbH, Frankfurt, } \\
\text { Germany) }\end{array}$ \\
\hline Dates & 02.06.15; 11.04.16; 07.03.2017 \\
\hline \multicolumn{2}{|l|}{ Amounts ${ }^{b}$} \\
\hline - $\mathrm{N}\left(47 \%\right.$ as $\mathrm{NO}_{3}-\mathrm{N}, 53 \%$ as $\left.\mathrm{NH}_{4}-\mathrm{N}\right)$ & $2.10 \mathrm{~g}$ pot equals approx. $122 \mathrm{~kg} \mathrm{ha}^{-1}$ \\
\hline - $\mathrm{P}\left(\right.$ as $\left.\mathrm{P}_{2} \mathrm{O}_{5}\right)$ & $0.30 \mathrm{~g}$ pot equals approx. $17 \mathrm{~kg} \mathrm{ha}^{-1}$ \\
\hline - $\mathrm{K}\left(\right.$ as $\left.\mathrm{K}_{2} \mathrm{O}\right)$ & $2.32 \mathrm{~g}$ pot equals approx. $134 \mathrm{~kg} \mathrm{ha}^{-1}$ \\
\hline - $\mathrm{Mg}$ (as $\mathrm{MgO})$ & $0.17 \mathrm{~g}$ pot equals approx. $10 \mathrm{~kg} \mathrm{ha}^{-1}$ \\
\hline - $\mathrm{S}$ & $1.12 \mathrm{~g}$ pot equals approx. $65 \mathrm{~kg} \mathrm{ha}^{-1}$ \\
\hline \multicolumn{2}{|l|}{ Harvesting } \\
\hline Cutting height & $5 \mathrm{~cm}$ above the soil surface \\
\hline Single cut regime & $\begin{array}{l}\text { Cup plant }(27.07 .15 ; 15.07 .16) \\
\text { Jerusalem artichoke }(11.08 .15 ; 04.08 .16)\end{array}$ \\
\hline Double cut regime & $\begin{array}{l}\text { Tall wheatgrass }(08.06 \text {. and } 20.08 .15 ; 12.07 . \text { and } 17.10 .16) \text {, } \\
\text { Giant knotweed (29.06. and } 02.09 .15 ; 11.06 \text {. and } 17.10 .16), \\
\text { Reed canary grass }(08.06 \text {. and } 11.08 .15 ; 11.07 \text {. and } 17.10 .16)\end{array}$ \\
\hline
\end{tabular}

a Parameters determined at the beginning of the experiment. ${ }^{\mathrm{b}}$ Recalculated to $\mathrm{kg} \mathrm{ha}^{-1}$ taking into consideration the higher plant densities in the pots compared to field conditions.

Five different plants species were cultivated in a two-year pot experiment from April 2015 until May 2017. Perennial energy crops, in particular the cup plant, tall wheatgrass, giant knotweed (Fallopia japonicum $x$ bohemica, 'IGNISCUM Candy'), and reed canary grass were vegetative propagated by dividing the rootstocks of mature plants prior to the experiment. Jerusalem artichoke (Helianthus tuberosus 'Gute Gelbe') was cultivated from tubers. In February 2015, pre-cultivation of the plants started in greenhouse using $9 \times 9 \mathrm{~cm}$ pots and a 20:30:50 vol.\% mixture of compost, soil and peat, respectively. After five weeks, 10 similarly developed plants of each species were selected and repotted into the prepared Kick-Brauckmann pots. For four weeks, the soil in the Kick-Brauckmann pots was kept moist to allow a good root formation. During the whole experiment, the pots were positioned under a rain shelter.

\subsection{Soil Moisture Treatments}

Soil types that are characterized by waterlogging, such as Stagnosols and Planosols, show waterlogging under mid European conditions particularly in autumn, winter and spring resulting from a considerable positive water balance during that period. In contrast to that, these soils are comparably dry in the summertime in Europe resulting from the restricted rooting depth and limited capillary water supply due to a dense, low conductance soil layer ('Sd' or 'Bg' horizon, acc. to [26] and [28], respectively). With our experimental design we aimed to constitute two different soil moisture treatments with each five pots per plant species. 
- The 'excess soil moisture' treatment (in the following referred to as 'EM') aimed to represent periodically excess soil water conditions during the winter half year, resulting from soil layers exhibiting very low percolation rates, as typical for Stagnosols and Planosols. In the context of this study, the term 'excess soil moisture' or 'waterlogging' defines soil water contents above field capacity $(\mathrm{pF} 1.8)$ at which large soil pores $(>50 \mu \mathrm{m})$ are filled up with water [29]. Such water contents represent the "wet end limit" at which air capacity is lost [30].

- The 'non-excess soil moisture' treatment (in the following referred to as ' $\mathrm{NM}^{\prime}$ ) aimed to represent soil conditions that allow for unrestricted deep percolation of soil water. This soil moisture treatment served as a control; $\mathrm{pF}$-values were generally below field capacity $(\mathrm{pF}>1.8)$.

\subsection{Determination of Soil Hydraulic Properties}

To relate volumetric soil water contents to soil water and air characteristics, the pore size distribution and bulk density were determined (Table 1). Twelve additional Kick-Brauckmann pots were prepared similar to the approach described in Section 2.1 and were also cultivated with different PECs. Four times in the course of the experiment, each three of these pots were used to sample undisturbed samples using $100 \mathrm{~cm}^{3}$ rings (six rings per pot). Samples were capillary saturated with water and subsequently stepwise $(60,300$ and $15,000 \mathrm{hPa})$ dewatered using pressure plates according to [31] followed by drying at $105^{\circ} \mathrm{C}$. Physiological relevant $\mathrm{pF}$-values can be estimated from the pore size distribution. The field capacity (FC; $\mathrm{pF} 1.8$ ) is defined by the total pore volume less the volume of pores $>50 \mu \mathrm{m}$. The permanent wilting point (PWP; $\mathrm{pF} 4.2$ ) is defined by soil texture and relates to the pores $<0.2 \mu \mathrm{m}$ and determined by water loss at $105^{\circ} \mathrm{C}$ of samples previously dewatered at $15,000 \mathrm{hPa}$ (Table 2).

Determination of particle size distribution was done by combined wet sieving and sedimentation after [32].

Table 2. Dynamics of pore size distribution and bulk density (mean values \pm standard deviation, $n=18$ ) in the course of the experiment.

\begin{tabular}{|c|c|c|c|c|c|c|}
\hline & & $\begin{array}{c}\text { 1st Sample } \\
(13.06 .15)\end{array}$ & $\begin{array}{c}\text { 2nd Sample } \\
(07.11 .15)\end{array}$ & $\begin{array}{c}\text { 3rd Sample } \\
(22.04 .16)\end{array}$ & $\begin{array}{c}\text { 4th Sample } \\
(29.01 .17)\end{array}$ & Mean \\
\hline Bulk density & $\mathrm{g} \mathrm{cm}^{-3}$ & $\begin{array}{c}1.26 \\
( \pm 0.05)\end{array}$ & $\begin{array}{c}1.31 \\
( \pm 0.05)\end{array}$ & $\begin{array}{c}1.34 \\
( \pm 0.08)\end{array}$ & $\begin{array}{c}1.38 \\
( \pm 0.08)\end{array}$ & $\begin{array}{c}1.32 \\
( \pm 0.08)\end{array}$ \\
\hline pores $>50 \mu \mathrm{m}$ & $\%$ & $\begin{array}{c}23.8 \\
( \pm 2.4)\end{array}$ & $\begin{array}{c}21.8 \\
( \pm 3.1)\end{array}$ & $\begin{array}{c}17.1 \\
( \pm 5.5)\end{array}$ & $\begin{array}{c}17.6 \\
( \pm 3.6)\end{array}$ & $\begin{array}{c}19.9 \\
( \pm 4.7)\end{array}$ \\
\hline pores $50-10 \mu \mathrm{m}$ & $\%$ & $\begin{array}{c}5.8 \\
( \pm 1.0) \\
\end{array}$ & $\begin{array}{c}7.3 \\
( \pm 0.5) \\
\end{array}$ & $\begin{array}{c}8.4 \\
( \pm 0.8)\end{array}$ & $\begin{array}{c}7.4 \\
( \pm 0.5)\end{array}$ & $\begin{array}{c}7.3 \\
( \pm 1.1) \\
\end{array}$ \\
\hline pores $10-0.2 \mu \mathrm{m}$ & $\%$ & $\begin{array}{c}12.4 \\
( \pm 1.3)\end{array}$ & $\begin{array}{c}10.9 \\
( \pm 1.6)\end{array}$ & $\begin{array}{c}13.7 \\
( \pm 3.7)\end{array}$ & $\begin{array}{c}14.9 \\
( \pm 2.5)\end{array}$ & $\begin{array}{c}13.0 \\
( \pm 2.9)\end{array}$ \\
\hline pores $<0.2 \mu \mathrm{m}$ & $\%$ & $\begin{array}{c}10.3 \\
( \pm 0.2)\end{array}$ & $\begin{array}{c}10.3 \\
( \pm 0.2)\end{array}$ & $\begin{array}{c}10.3 \\
( \pm 0.2)\end{array}$ & $\begin{array}{c}10.3 \\
( \pm 0.2)\end{array}$ & $\begin{array}{c}10.3 \\
( \pm 0.2)\end{array}$ \\
\hline $\begin{array}{l}\text { Total pore } \\
\text { volume }\end{array}$ & $\%$ & $\begin{array}{c}52.3 \\
( \pm 2.1) \\
\end{array}$ & $\begin{array}{c}50.1 \\
( \pm 1.6)\end{array}$ & $\begin{array}{c}49.6 \\
( \pm 3.1) \\
\end{array}$ & $\begin{array}{c}47.9 \\
( \pm 3.0) \\
\end{array}$ & $\begin{array}{c}49.9 \\
( \pm 2.9) \\
\end{array}$ \\
\hline Field capacity & $\%$ & $\begin{array}{c}28.5 \\
( \pm 0.6)\end{array}$ & $\begin{array}{c}29.1 \\
( \pm 2.4)\end{array}$ & $\begin{array}{c}32.4 \\
( \pm 3.6)\end{array}$ & $\begin{array}{c}31.2 \\
( \pm 1.5)\end{array}$ & $\begin{array}{c}30.4 \\
( \pm 2.8)\end{array}$ \\
\hline $\begin{array}{c}\text { Plant usable } \\
\text { water capacity }\end{array}$ & $\%$ & $\begin{array}{c}18.2 \\
( \pm 0.6)\end{array}$ & $\begin{array}{l}18.8 \\
( \pm 2.4)\end{array}$ & $\begin{array}{c}22.1 \\
( \pm 3.6)\end{array}$ & $\begin{array}{c}21.9 \\
( \pm 2.6)\end{array}$ & $\begin{array}{c}20.4 \\
( \pm 3.1)\end{array}$ \\
\hline
\end{tabular}

\subsection{Crop Management}

\subsubsection{Adjustment of Soil Water Contents}

Starting from June 2015, watering of the plants in the pots was done to reach a predefined nominal value. The nominal values were estimated from two integrative soil moisture sensors in the field (0 to 
$50 \mathrm{~cm}$, EnviroScan ${ }^{\circledR}$ Soil Moisture Probes, Sentek Pty Ltd., Adelaide, Australia) that were installed in a soil exhibiting stagnating soil water and a soil that allowed unimpeded deep percolation. In the second year of the experiment, we deviated from this scheme in order to intensify the differences more clearly between both soil moisture treatments (Figure 2). The present water contents in the pots were obtained by reading the installed FD-sensors. The water deficit was calculated separately for each plant species and treatment by comparing the current soil moisture contents in the pots and the nominal value. The compensation of the water deficit was done manually by watering on top of the soil; this was done daily during periods of hot weather conditions to once a week during winter (Figure 3).

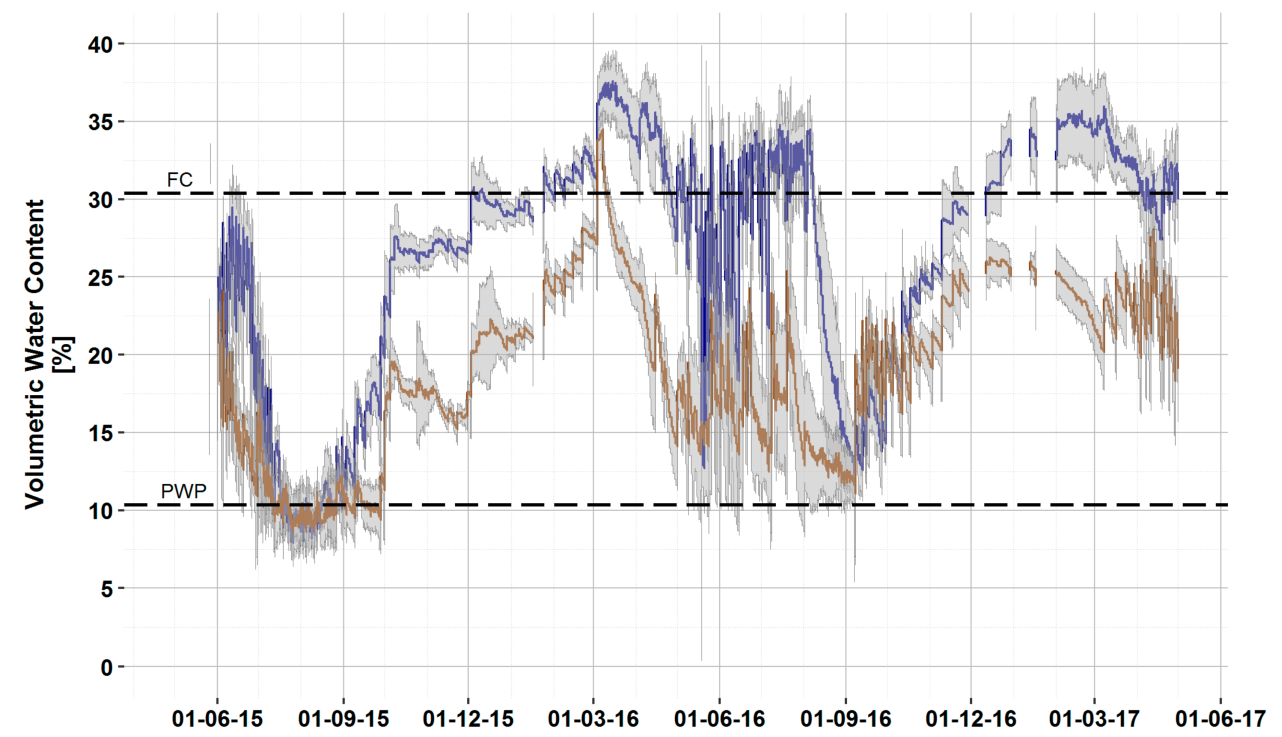

Figure 2. Course of the volumetric water contents of the excess soil moisture ('EM') (blue) and the non-excess soil moisture ('NM') (brown) treatment. Grey shaded areas represent the range of the sensors. Additionally, the permanent wilting point ( $\mathrm{PWP}, \mathrm{pF}=4.2$, water contents $(\mathrm{WC})=10.3 \mathrm{vol} . \%$ ) and field capacity ( $\mathrm{FC}, \mathrm{pF}=1.8, \mathrm{WC}=30.4$ vol.\%) are shown. Gaps in the graph were due to periods of frost.

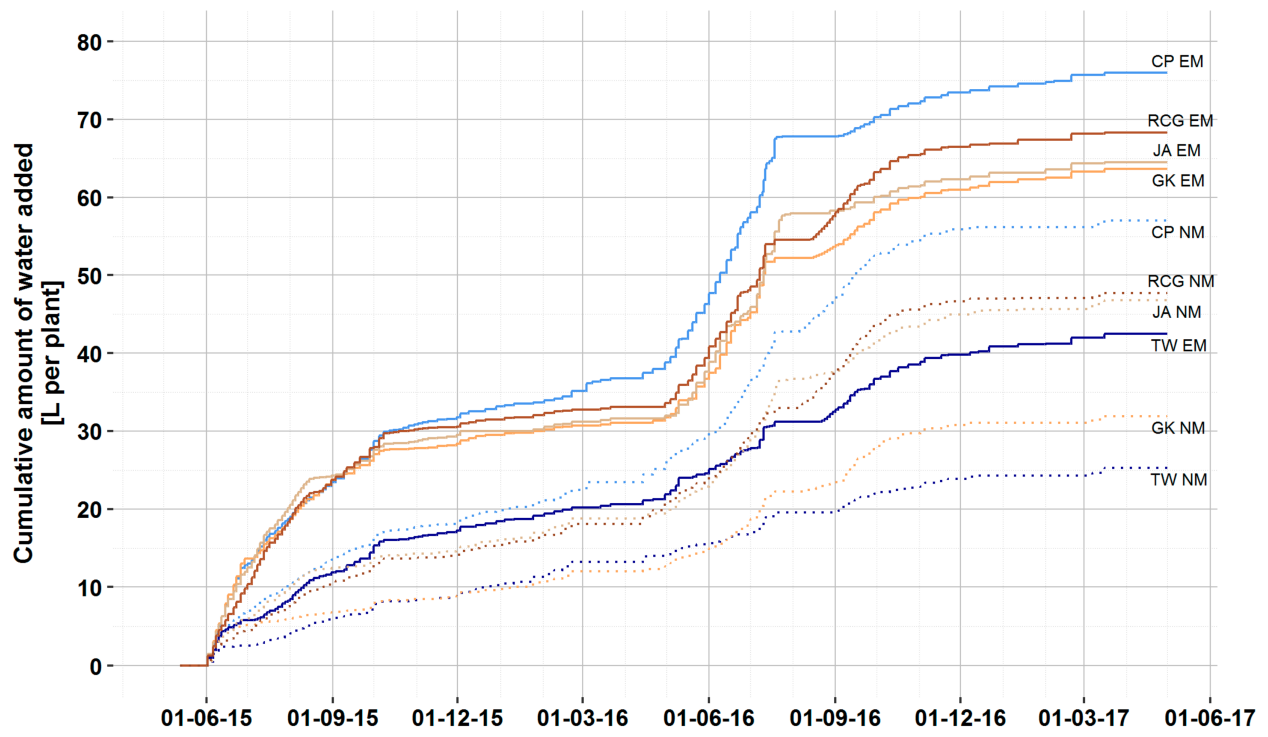

Figure 3. Cumulative representation of the amounts of water added to the plants in the course of the experiment. Abbreviations of the plant names are as follows: cup plant: 'CP', tall wheatgrass: 'TW', giant knotweed: 'GK', Jerusalem artichoke: 'JA' and reed canary grass: 'RCG'. Soil moisture treatments were abbreviated as 'EM' (excess soil moisture) and 'NM' (non-excess soil moisture). 


\subsubsection{Fertilization}

Fertilization was oriented on practice-relevant levels taking into consideration the higher plant densities in the pots compared to field conditions. In each year of the experiment, all pots received a single fertilizer dressing at the beginning of the vegetation period which was applied to the soil surface and shallowly mixed in (Table 1).

\subsubsection{Harvesting of Shoot Biomass}

Harvesting of the shoot biomass was done manually using shears after measuring plant height using a folding ruler. Harvest dates and cutting frequency were chosen species-specific aiming to reach dry matter contents of approx. $30 \%$ (suitable for ensiling), similar to harvest dates of the crops in agricultural practice (Table 1). Harvested shoot biomass was dried at $105^{\circ} \mathrm{C}$ in a compartment drier for determination of the dry weight.

\subsection{Soil Sampling and Pretreatment for Analysis}

First soil sampling to determine the initial state of the bulk soil was done prior to the start of the experiment. After one year of the experiment (4 April 2016), sampling from the pots was done using an auger $(\varnothing 35 \mathrm{~mm})$ to determine changes of the $\mathrm{pH}$ value of the soil. The borehole was again filled up with the soil that was used for pot preparation at the beginning of the experiment. Close to the end of the experiment (26 April 2017), soil samples were taken in a similar manner.

Moist soil samples were stored cool until analysis. In contrast to common procedure, no pre-preparation of the soil, in particular drying and sieving, was done aiming to reduce the modifications and to precisely reflect conditions in the pots.

\subsection{Soil Chemical and Microbial Characterization}

Soil water contents were determined separately for each sample by water loss at $105^{\circ} \mathrm{C}$ for $24 \mathrm{~h}$. Soil $\mathrm{pH}$ measurement was done in a $0.01 \mathrm{M} \mathrm{CaCl}_{2}$ solution using a $\mathrm{pH} /$ Cond $340 \mathrm{i}$ glass electrode (WTW, Weilheim, Germany). For determination of soil organic carbon (SOC) and nitrogen $\left(\mathrm{N}_{\text {tot }}\right)$ contents, a subsample was dried at $105{ }^{\circ} \mathrm{C}$ until constant weight was reached and grinded up using an agate mortar. Measurement was done using an Elemental Analyser EA3000 Series (HEKAtech, Wegberg, Germany).

Microbial biomass $C\left(C_{\text {mic }}\right)$ was determined by the chloroform fumigation extraction method according to [33]. Extraction was performed with a $0.01 \mathrm{M} \mathrm{CaCl}_{2}$ solution. Measurement was done with a TOC-TN Analyzer (Shimadzu TOC-V+TNN). $\mathrm{C}_{\text {mic }}$ contents were calculated using a $\mathrm{k}_{\mathrm{EC}}$-coefficient of 0.45 as stated by [34].

Aerobic soil respiration was determined using the alkali-absorption method according to [35] as described by [36]. The method is based on the fixation of soil-released $\mathrm{CO}_{2}$ by a sodium hydroxide solution $(\mathrm{NaOH})$ in an enclosed system. First, $20 \mathrm{~mL} 0.05 \mathrm{M} \mathrm{NaOH}$ were pipetted into 250-mL flasks. Moist soil samples equivalent to $10 \mathrm{~g}$ dry soil were filled in wide neck plastic tubes and placed in the flasks. Incubation was done for $48 \mathrm{~h}$ at $25^{\circ} \mathrm{C}$. Each sample was prepared in triplicate. To account for the $\mathrm{CO}_{2}$ enclosed in the headspace of the flasks, five blank samples were also prepared. After addition of $2 \mathrm{~mL}$ of barium chloride $\left(\mathrm{BaCl}_{2}, 0.5 \mathrm{M}\right)$ as the precipitating agent and three drops of phenolphthalein as the $\mathrm{pH}$-indicator, the $\mathrm{NaOH}$ solution was titrated with $0.05 \mathrm{M}$ hydrochloric acid $(\mathrm{HCl})$ until color change of the indicator to determine the amount of $\mathrm{NaOH}$ that was necessary for fixation of $\mathrm{CO}_{2}$. Calculation of the respiration rate was done using a conversion factor of $1.1 \mathrm{mg} \mathrm{CO}$ per $1 \mathrm{~mL} \mathrm{NaOH}$ consumed.

Estimation of the soil metabolic status was done by determination of dehydrogenase activity according to the method of [37], slightly modified by [38]. Moist soil equivalent to $2.5 \mathrm{~g}$ of dry soil was incubated with $2.5 \mathrm{~mL}$ triphenyl tetrazolium chloride (TTC) solution dissolved in $0.1 \mathrm{M}$ Tris (hydroxymethyl) aminomethane buffer at $25^{\circ} \mathrm{C}$ for $24 \mathrm{~h}$ in closed tubes. The Tris buffer was adjusted with $\mathrm{HCl}$ to a $\mathrm{pH}$ of 7.6 and a TTC concentration of $0.5 \%$ was chosen. Each soil sample was incubated in 
triplicate with one additional blank sample without TTC addition. After incubation, formed triphenyl formazan (TPF) was extracted from the soil matrix with $11.5 \mathrm{~mL}$ of acetone. The suspension was placed in the dark for $2 \mathrm{~h}$ and was shaken every $30 \mathrm{~min}$. After filtration, the measurement of TPF was done by using a photospectrometer (Shimadzu UV-1650 PC; Shimadzu Europe GmbH, Duisburg, Germany) at a wavelength of $546 \mathrm{~nm}$.

\subsection{Determination of Root Biomass}

Analysis of the root biomass was done at the end of the experiment in late April 2017. Therefore, the root ball that firmly held the soil together was carefully removed from the pot. The rootstock was subdivided into its top and bottom part as shown in Figure 1 using a spade. Roots were carefully washed out to remove all soil particles followed by hand-sorting to separate vital from dead roots. Vital roots were air dried on paper towels until no free water was present. After weighting of the fresh root biomass, roots were dried at $105^{\circ} \mathrm{C}$ for $48 \mathrm{~h}$ for determination of dry mass.

\subsection{Data Processing and Statistical Analysis}

Data about water contents in the field as well as in the pots were first checked for plausibility. Failures of individual sensors were removed from the time series. Correlation with air temperature data allowed removing values logged during periods of frost from the time series. Mean values and variation of the sensors for the specific crops and soil moisture treatment were calculated.

Statistical analysis of the data was done using RStudio programming language version 3.3.2 [39]. For plants that were treated in double cut regimes, the sum of plant heights and biomass yields of both cuts were used for statistical analysis. Testing for differences in growth and soil parameters on annual basis was always done between both soil moisture treatment (EM and NM) of a specific crop using two sample t-tests and Wilcoxon signed rank test, depending on normality assumption, which was tested prior using the Shapiro-Wilk-tests. For root biomass and distribution, testing was furthermore done by subdividing into the top and bottom layer of the pot. The water-use efficiency (WUE) was calculated as a rough estimate from the total biomass development and the amount of water added during the experiment neglecting evaporation.

\section{Results}

\subsection{Soil Physical Parameters in the Course of the Experiment}

Pore size distribution and bulk density did not show significant variations in the course of the experiment. Total pore volume was $49.9 \pm 2.9 \%$ and showed a slightly descending trend from $52.3 \pm 2.1 \%$ at the beginning of the experiment to $47.9 \pm 3.0 \%$ at the end, probably resulting from soil settlement (Table 2). Similarly, the bulk density increased from $1.26 \pm 0.05 \mathrm{~g} \mathrm{~cm}^{-3}$ to $1.38 \pm 0.08 \mathrm{~g} \mathrm{~cm}^{-3}$ with a mean value of $1.32 \pm 0.08 \mathrm{~g} \mathrm{~cm}^{-3}$. The settlement primarily affected the number of pores with a size larger than $50 \mu \mathrm{m}$ which were reduced from $23.8 \pm 2.4 \%$ to $17.6 \pm 3.6 \%$, whereas the proportions of smaller pores remained quite constant during the experimental period. Thus, volumetric water contents of $10.3 \pm 0.2$ vol.\% indicate the permanent wilting point (PWP; $\mathrm{pF}$-value of 4.2 ). Field capacity (FC; pF-value of 1.8) was reached when water contents were $30.4 \pm 2.8 \%$.

\subsection{Soil Moisture Dynamics in the Pots and Implications for Aeration of the Soil}

At the start of the experiment (Figure 2; Table 3), from July to September 2015, the soils of both treatments were kept comparably dry with soil water contents (WC) only slightly above the PWP, based on values obtained by field moisture sensors. In October and November 2015, the EM treatment was adjusted to WCs close to FC. Permanent exceedance of FC was realized from February to April 2016 (Table 3). During that time, we observed that the mean water levels in the pots were approx. 10 to $15 \mathrm{~cm}$ below the soil surface. The NM treatment was kept at WCs between 15-25 vol.\% at that time. In spring and summer of the second year of the experiment, the EM and NM treatments were 
adjusted to mean WCs of $20-25$ vol. $\%$ and 15 vol.\%, respectively. However, resulting from the high water consumption of the plants, particularly in the EM treatment, large amounts of water had to be added. This resulted in the "turbulent" appearance of the WCs during summer 2016 (Figure 2). Starting from September 2016, the WCs were again raised. In the EM treatment, FC exceeded from the beginning of December 2016 to the end of March 2017. During that time, the NM treatment was kept at WCs between 20 and 25 vol.\% until the end of the experiment (Figure 2).

Table 3. Summary of volumetric soil water contents (WCs) on a monthly basis for both treatments during the experimental period. Median values of volumetric soil water content, proportional exceedances of the permanent wilting point (WC $<\mathrm{PWP}, \mathrm{pF}<4.2, \mathrm{WC}<10.3$ vol. $\%$ ) and field capacity (WC $>$ FC, $\mathrm{pF}>1.8, \mathrm{WC}>30.4$ vol. $\%$ ) are shown.

\begin{tabular}{ccccccc}
\hline Treatment & \multicolumn{2}{c}{ Excess Soil Moisture ('EM') } & \multicolumn{2}{c}{ Non-Excess Soil Moisture ('NM') } \\
\hline Month & Median WC & WC < PWP & WC > FC & Median WC & WC < PWP & WC > FC \\
\hline Vol.\% & \% of Time & \% of Time & Vol.\% & \% of Time & \% of Time \\
\hline May '15 & 25.6 & 0 & 50.0 & 25.9 & 0 & 50.0 \\
June '15 & 24.9 & 0 & 0 & 15.5 & 0 & 0 \\
July '15 & 10.9 & 44.2 & 0 & 10.5 & 47.7 & 0 \\
August '15 & 10.2 & 55.0 & 0 & 9.8 & 80.0 & 0 \\
September '15 & 16.2 & 0 & 0 & 10.3 & 53.6 & 0 \\
October '15 & 26.5 & 0 & 0 & 17.7 & 0 & 0 \\
November '15 & 26.9 & 0 & 0 & 16.3 & 0 & 0 \\
December'15 & 29.7 & 0 & 15.1 & 21.2 & 0 & 0 \\
January '16 & 29.4 & 0 & 42.6 & 21.3 & 0 & 0 \\
Febeuary '16 & 31.7 & 0 & 92.8 & 25.9 & 0 & 0 \\
March '16 & 36.3 & 0 & 100.0 & 27.3 & 0 & 23.3 \\
April '16 & 34.0 & 0 & 86.0 & 20.4 & 0 & 0 \\
May '16 & 28.1 & 0 & 47.9 & 16.3 & 0 & 0 \\
June '16 & 31.3 & 0 & 56.7 & 16.7 & 0 & 0 \\
July '16 & 32.6 & 0 & 83.6 & 17.2 & 0 & 0 \\
August '16 & 22.3 & 0 & 24.4 & 13.3 & 0 & 0 \\
September'16 & 15.0 & 0 & 0 & 18.1 & 0 & 0 \\
October '16 & 23.0 & 0 & 0 & 19.8 & 0 & 0 \\
November '16 & 28.6 & 0 & 0 & 23.5 & 0 & 0 \\
December '16 & 31.1 & 0 & 99.9 & 25.6 & 0 & 0 \\
January '17 & 34.1 & 0 & 100.0 & 25.4 & 0 & 0 \\
Febeuary '17 & 35.0 & 0 & 100.0 & 24.0 & 0 & 0 \\
March '17 & 33.1 & 0 & 100.0 & 23.0 & 0 & 0 \\
April '17 & 30.5 & 0 & 55.6 & 22.7 & 0 & 0 \\
\hline
\end{tabular}

\subsection{Shoot Biomass Development and Water Consumption}

In the first year of the experiment, height of the PECs was not significantly influenced by soil moisture treatment (Table 4). However, shoot biomass yields based on dry matter were up to double as high in the EM compared to the NM treatments of all plant species. The highest shoot biomass in 2015 in the EM was reached by giant knotweed with $74.5 \pm 6.3 \mathrm{~g} \mathrm{DW} \mathrm{pot}^{-1}$; in the NM treatment it was highest for the Jerusalem artichoke with $39.0 \pm 3.7 \mathrm{~g} \mathrm{DW} \mathrm{pot}^{-1}$. In 2016, all PECs showed a significantly positive response to the EM treatment with respect to growth parameters (Table 4). In 2016, the plant height of all species of the EM treatment was significantly larger than that of the NM treatment corresponding to the biomass yields. Yields were two to three times higher in the EM compared to the NM treatment. In sum, the harvested biomasses of the EM treatments were about two times as high as for the NM treatment, for all species. The rough estimation of the WUE showed significant differences between both soil moisture treatments for the cup plant, Jerusalem artichoke and reed canary grass with higher efficiencies for each observed in the EM treatment. In contrast, the WUE of giant knotweed and tall wheatgrass were quite similar for both soil moisture treatments. 
Table 4. Growth parameters (mean values \pm standard deviation, $n=5$ ) of tested plant species for both experimental years and as a summary value for the whole experiment. Significant differences between both soil moisture treatments ('EM': excess soil moisture, 'NM': non-excess soil moisture) of a certain species are indicated as follows: ${ }^{\circ}:<0.10,^{*}:<0.05,{ }^{* *}:<0.01, * * *:<0.001$.

\begin{tabular}{|c|c|c|c|c|c|c|c|}
\hline \multirow{3}{*}{ Species } & \multirow{3}{*}{ Treatment } & \multicolumn{2}{|c|}{2015} & \multicolumn{2}{|c|}{2016} & \multicolumn{2}{|c|}{ Total } \\
\hline & & Height ${ }^{\#}$ & Shoot Biomass \# & Height ${ }^{\#}$ & Shoot Biomass \# & Shoot Biomass & WUE \\
\hline & & m & g DW Pot'-1 & $\mathbf{m}$ & g DW Pot'-1 & g DW Pot ${ }^{-1}$ & g DW L L \\
\hline \multirow{2}{*}{ Cup plant } & EM & $1.08( \pm 0.13)$ & $46.9( \pm 6.2)^{* *}$ & $1.17( \pm 0.13)^{* *}$ & $170.4( \pm 35.4)^{* * *}$ & $217.3( \pm 35.9)^{* *}$ & $2.90( \pm 0.56) *$ \\
\hline & NM & $0.93( \pm 0.12)$ & $32.2( \pm 3.9)$ & $0.71( \pm 0.16)$ & $69.3( \pm 13.8)$ & $101.5(+17.4)$ & $1.78( \pm 0.30)$ \\
\hline \multirow{2}{*}{$\begin{array}{l}\text { Jerusalem } \\
\text { artichoke }\end{array}$} & EM & $0.97( \pm 0.22)$ & $65.1( \pm 7.5)^{* *}$ & $1.70( \pm 0.10)^{* * *}$ & $186.8( \pm 33.9)^{* *}$ & $252.0( \pm 8.7)^{* * *}$ & $3.91( \pm 0.13)^{* * *}$ \\
\hline & NM & $0.84( \pm 0.07)$ & $39.0( \pm 3.7)$ & $1.07( \pm 0.08)$ & $84.3( \pm 6.6)$ & $123.3( \pm 10.2)$ & $2.63( \pm 0.22)$ \\
\hline \multirow{2}{*}{ Giant knotweed } & EM & $1.44( \pm 0.19)$ & $74.5( \pm 6.3)^{* * *}$ & $1.54( \pm 0.13)^{* *}$ & $147.8( \pm 4.4)^{* * *}$ & $222.3( \pm 8.5)^{* * *}$ & $3.49( \pm 0.13)$ \\
\hline & NM & $1.39( \pm 0.18)$ & $35.1( \pm 6.9)$ & $1.23( \pm 0.06)$ & $77.4( \pm 11.4)$ & $112.5( \pm 15.3)$ & $3.53( \pm 0.48)$ \\
\hline \multirow{2}{*}{ Tall wheatgrass } & EM & $1.89( \pm 0.23)$ & $29.6( \pm 10.6)$ & $1.90( \pm 0.09)$ * & $81.2( \pm 14.3)^{* *}$ & $110.8( \pm 17.8)^{\circ}$ & $2.22( \pm 1.07)$ \\
\hline & NM & $1.67( \pm 0.19)$ & $25.7( \pm 2.1)$ & $1.51( \pm 0.25)$ & $30.6( \pm 4.4)$ & $56.3( \pm 6.0)$ & $2.23( \pm 0.24)$ \\
\hline \multirow{2}{*}{ Reed canary grass } & EM & $1.37( \pm 0.08)$ & $50.2( \pm 4.4)^{* * *}$ & $1.81( \pm 0.16)^{* * *}$ & $112.6( \pm 8.2)^{* * *}$ & $162.8( \pm 11.3)^{* * *}$ & $2.38( \pm 0.16)^{* * *}$ \\
\hline & NM & $1.26( \pm 0.14)$ & $26.0( \pm 3.2)$ & $1.31( \pm 0.16)$ & $61.4( \pm 2.8)$ & $87.4( \pm 5.3)$ & $1.83( \pm 0.11)$ \\
\hline
\end{tabular}

\# Results were cumulated for plant species that were harvested in double cut regimes (giant knotweed, tall wheatgrass, reed canary grass). WUE: water-use efficiency. 


\subsection{Root Biomass and Root Distribution}

Total amounts of root biomass showed large differences between the different PECs (Figure 4a). Giant knotweed and reed canary grass had the biggest root biomass in both soil moisture treatments which were three to four times larger compared to the Jerusalem artichoke and tall wheatgrass. The total root biomass of the cup plant significantly depended on the soil moisture treatment. In the EM treatment, $40.5 \pm 8.1 \mathrm{~g} \mathrm{pot}^{-1}$ compared to $184.6 \pm 39.2 \mathrm{~g} \mathrm{pot}^{-1}$ in the NM treatment $(p<0.001)$ were measured. The inverse situation was observed for giant knotweed. Here, the total root biomass was, with $194.3 \pm 18.1 \mathrm{~g} \mathrm{pot}^{-1}$ compared to $114.2 \pm 29.6 \mathrm{~g} \mathrm{pot}^{-1}$, significantly higher $(p=0.002)$ in the EM treatment. Differences in absolute root biomass among both treatments of a certain species and a certain layer (top or bottom; Figure 1) were found for the cup plant, each with a higher root biomass in the NM treatment as well as for the top layer of giant knotweed $(p<0.001)$ and the bottom layer of reed canary grass.

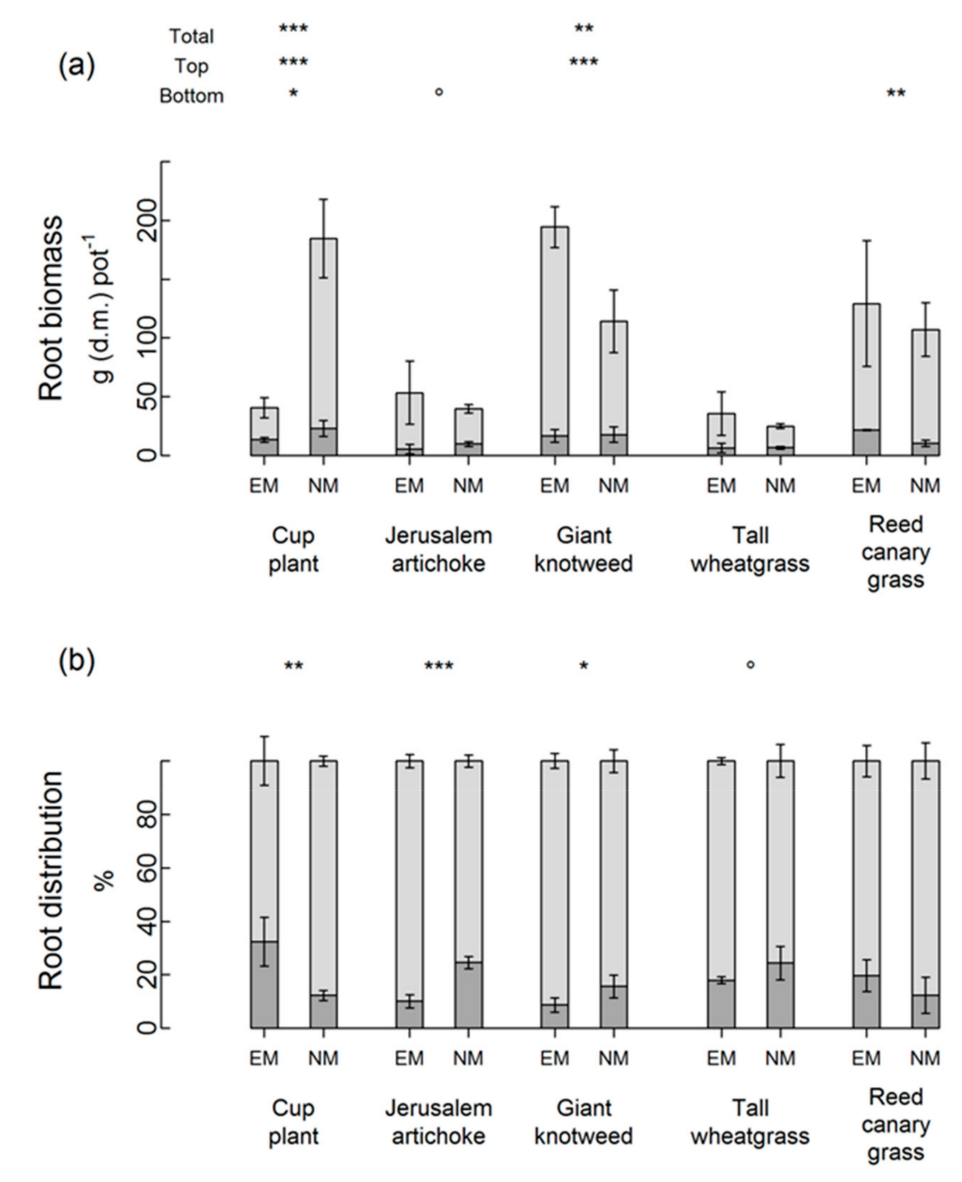

Figure 4. Biomass (a) and relative distribution (b) of plant roots in the top (light grey) and bottom (dark grey) layer of the pots including error bars representing a range of \pm one standard deviation $(n=5)$. Testing using the t-test and U-test aimed to detect differences for a certain layer between both soil moisture treatments ('EM': excess soil moisture, 'NM': non-excess soil moisture) of a specific plant. Significant differences are indicated as follows: ${ }^{\circ}:<0.10, *:<0.05,{ }^{* *}:<0.01,{ }^{* * *}:<0.001$.

The relative root distribution showed that typically $15 \%$ to $30 \%$ of the root biomass is found in the bottom layer (Figure 4b). For the Jerusalem artichoke, giant knotweed and tall wheatgrass, the proportion of roots in the bottom layer was significantly higher in the NM compared to the EM treatment of the same species. For reed canary grass, no difference could be found. In contrast to that, the relative share of the cup plants' roots was 32.3\% significantly higher $(p=0.007)$ in the bottom layer of EM compared to $12.3 \%$ in the NM treatment. 


\subsection{Dynamics in Soil $p H$}

In the course of the experiment, the soil $\mathrm{pH}$ underwent distinct changes depending on soil moisture treatment and plant species. Starting at an initial $\mathrm{pH}$ value of 5.9 , it ranged between $4.7 \pm 0.3$ and $6.2 \pm 0.2$ at the end of the experiment. The soil $\mathrm{pH}$ of a certain species was always higher in the EM than in the NM treatment. At both sampling dates, the soil $\mathrm{pH}$ values were significantly different between both soil moisture treatments of the grass species (Figure 5a). In the EM treatment, the $\mathrm{pH}$ values slightly increased or were at least constant. In contrast, the $\mathrm{pH}$ values declined down to values between $4.7 \pm 0.3$ and $5.4 \pm 0.4$ in the $\mathrm{NM}$ treatment. The $\mathrm{pH}$ values of the forbs showed a similar behavior during this time (Figure $5 b$ ); however, the $\mathrm{pH}$ values of the soils cultivated with forbs showed in general a more pronounced decline compared to the grasses. Significant differences between both soil moisture treatments of forb species could also be observed except for the Jerusalem artichoke. Only for the Jerusalem artichoke could no difference between both soil moisture treatments be observed at the end of the experiment; the $\mathrm{pH}$ values of the EM and the NM treatment declined to values of $5.0 \pm 0.4$ and $4.9 \pm 0.4$, respectively.
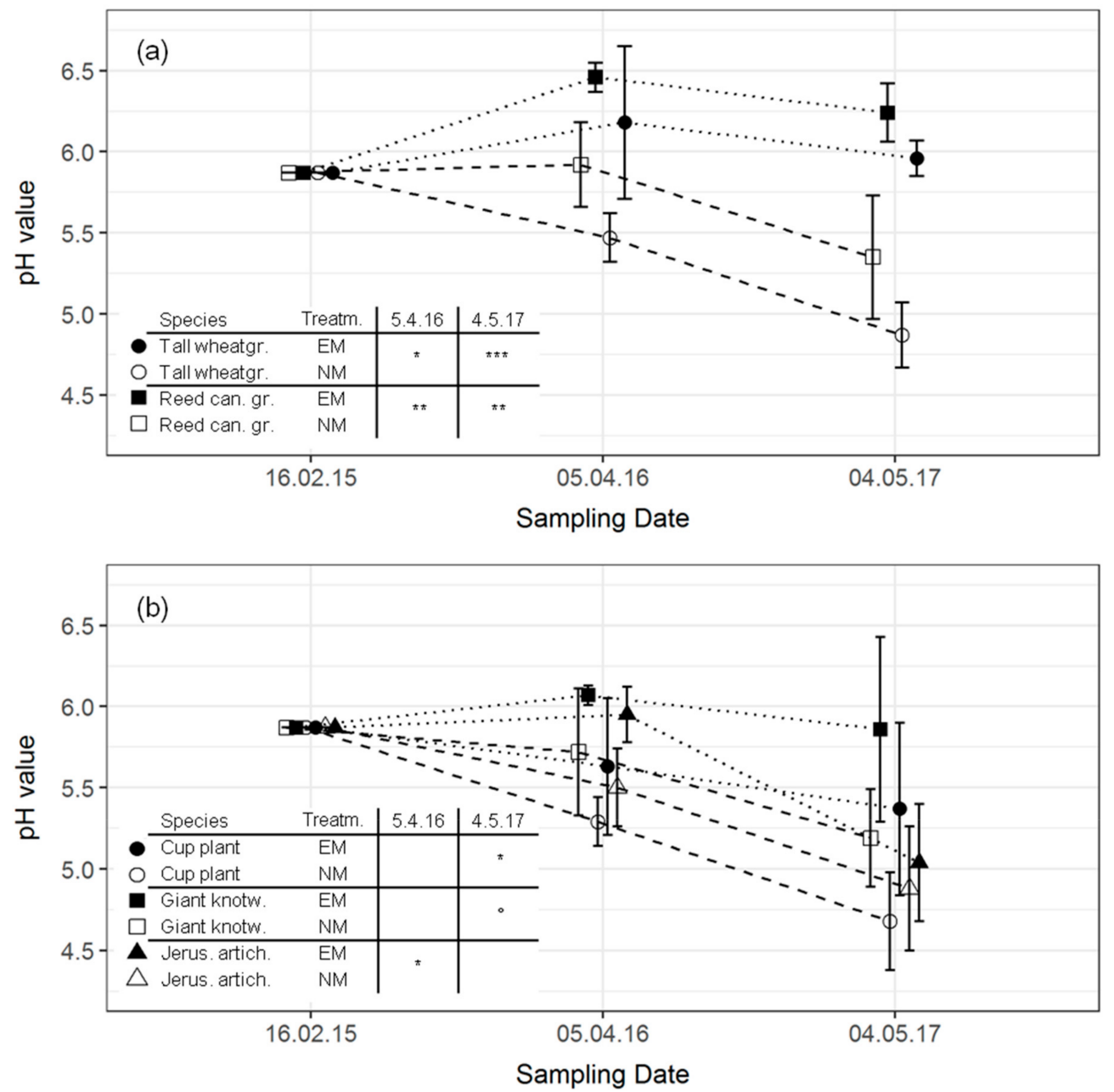

Figure 5. Change of soil $\mathrm{pH}$ value (mean values \pm standard deviation, $n=5$ ) as affected by different soil moisture treatments and plant species $(n=5)$. For reasons of readability, the figure was split into subplots of (a) grasses and (b) forbs species. Significant differences between both soil moisture treatments ('EM': excess soil moisture, 'NM': non-excess soil moisture) of a certain plant species at single sampling dates are indicated as follows: ${ }^{\circ}:<0.10,{ }^{*}:<0.05, * *:<0.01, * * *:<0.001$. 


\subsection{Soil Parameters Affected by Soil Moisture Treatment and Plant Species}

SOC contents distinctly increased during the experimental period from an initial value of $13.0 \mathrm{~g} \mathrm{~kg}^{-1}$ to values of approximately $20 \mathrm{~g} \mathrm{~kg}^{-1}$. At the end of the experiment, the highest SOC content was detected for the cup plant EM $\left(20.89 \pm 1.62 \mathrm{~g} \mathrm{~kg}^{-1}\right)$ and the lowest for the Jerusalem artichoke EM $\left(18.49 \pm 0.40 \mathrm{~g} \mathrm{~kg}^{-1}\right)$. However, a relationship of SOC increase and plant species or soil moisture treatment was in most cases not significant (Table 5). SOC contents were only significantly different $(p=0.04)$ for giant knotweed with $20.23 \pm 0.81 \mathrm{~g} \mathrm{~kg}^{-1}$ in the EM and $18.95 \pm 0.74 \mathrm{~g} \mathrm{~kg}^{-1}$ in the NM treatment. A significant increase in total soil nitrogen $\left(\mathrm{N}_{\text {tot }}\right)$ during the experiment was observed. In contrast to the SOC values, $\mathrm{N}_{\text {tot }}$ values were always higher in the $\mathrm{NM}$ treatment. A significant difference between both soil moisture treatments was found for the Jerusalem artichoke $(p=0.03)$ and tall wheatgrass $(p=0.09)$.

Amounts of soil microbial biomass $\left(\mathrm{C}_{\text {mic }}\right)$ were in a wide range relating to the different plant species and soil moisture treatments. $C_{\text {mic }}$ was largest in giant knotweed $N M$ with $253.5 \pm 73.7 \mu \mathrm{g} \mathrm{g}^{-1}$ d.m. and lowest in Jerusalem artichoke NM with $116.9 \pm 31.5 \mu \mathrm{g} \mathrm{g}^{-1}$ d.m. However, within the various species, differences among both soil moisture treatments were quite small. Significant differences could solely be observed for the Jerusalem artichoke with $187.8 \pm 41.0 \mu \mathrm{g} \mathrm{g}^{-1} \mathrm{~d}$.m. in the EM and $116.9 \pm 31.5 \mu \mathrm{g} \mathrm{g}^{-1} \mathrm{~d} . \mathrm{m}$. in the NM treatment $(p=0.03)$. Amounts of $C_{\text {mic }}$ were in trend (without being statistically significant) higher in the NM treatment of grass species. This trend was inverse for forbs. The $C_{\text {mic }}$ to $C_{\text {org }}$ ratio reflected the variability of the $C_{\text {mic }}$ values (Table 5). The highest values were observed for tall wheatgrass NM $(1.31 \pm 0.25 \%)$ and lowest for the Jerusalem artichoke $\mathrm{NM}(0.61 \pm 0.16 \%)$, respectively. Similar to $C_{\text {mic }}$, the $C_{\text {mic }}$ to $C_{\text {org }}$ ratio was steadily higher in the EM treatment of grasses and lower in the EM treatment of the forbs. However, significant differences at the $5 \%$ level could only be observed for the Jerusalem artichoke.

Dehydrogenase activity (DHA) showed a large range of measured value. The highest DHA, measured in the cup plant EM $\left(220.8 \pm 111.1 \mu \mathrm{g}\right.$ TPF $\left.\mathrm{g}^{-1} \mathrm{~d} . \mathrm{m} . \mathrm{h}^{-1}\right)$, was 20 times larger than the lowest value $\left(11.8 \pm 10.6 \mu \mathrm{g}\right.$ TPF g $\left.{ }^{-1} \mathrm{~d} . \mathrm{m} . \mathrm{h}^{-1}\right)$ measured in the Jerusalem artichoke. In trend, soils cultivated with forbs were characterized by higher DHA compared to grasses. EM treatments were characterized by higher DHA than NM except for giant knotweed. Resulting from generally large variability determined for a certain species and soil moisture treatment, the differences in DHA between both soil moisture treatments were only significant for the cup plant $(p=0.03)$ and the Jerusalem artichoke $(p=0.03)$.

Soil aerobic respiration ranged between $0.39 \pm 0.29 \mu \mathrm{g} \mathrm{CO} \mathrm{CO}_{2}-\mathrm{C} \mathrm{g}^{-1} \mathrm{~d} . \mathrm{m}$. (Jerusalem artichoke NM) and $3.00 \pm 0.55 \mu \mathrm{g} \mathrm{CO}_{2}-\mathrm{C} \mathrm{g}^{-1} \mathrm{~d}$.m. (cup plant NM). Strikingly, the respiration was significantly higher in the in EM treatment of all species. No distinctive differences were found for respiration rates of forbs and grasses.

Significant differences between soil moisture treatments were also found in the metabolic quotients $\left(\mathrm{qCO}_{2}\right)$. Thus, the $\mathrm{qCO}_{2}$ of the EM treatments were steadily higher than that of the NM treatments. In the $\mathrm{NM}$ treatments, the values ranged from $2.44 \pm 0.47$ (tall wheatgrass) to $6.17 \pm 0.81 \mu \mathrm{g} \mathrm{CO}-\mathrm{C} \mathrm{mg}^{-1} \mathrm{C}_{\mathrm{mic}}$ $\mathrm{g}^{-1}$ d.m. $\mathrm{h}^{-1}$ (cup plant), whereas significantly higher values were observed in the EM treatments ranging from $6.72 \pm 1.31$ for giant knotweed to $11.53 \pm 1.14 \mu \mathrm{g} \mathrm{CO}{ }_{2}-\mathrm{C} \mathrm{mg}^{-1} \mathrm{C}_{\text {mic }} \mathrm{g}^{-1} \mathrm{~d} . \mathrm{m} . \mathrm{h}^{-1}$ for the cup plant. 
Table 5. Soil chemical and microbial parameters (mean values \pm standard deviation, $n=5)$. Amounts of soil microbial biomass $\left(\mathrm{C}_{\mathrm{mic}}\right)$, dehydrogenase activity (DHA) and soil respiration were measured at given soil water contents without any pretreatment in order not to modify the conditions present in the soil. Significant differences between both soil moisture treatments ('EM': excess soil moisture, 'NM': non-excess soil moisture) of a certain species are indicated as follows: ${ }^{\circ}$ : $<0.10$, $*$ : $<0.05,{ }^{* *}:<0.01, * *:<0.001$. SOC: soil organic carbon, TPF: triphenyl formazan.

\begin{tabular}{|c|c|c|c|c|c|c|c|c|}
\hline Species & Treatment & SOC & $\mathbf{N}_{\text {tot }}$ & $\mathrm{C}_{\text {mic }}$ & $C_{\text {mic }}$ to $C_{\text {org }}$ & DHA & Respiration & Metab. Quotient \\
\hline & & $\mathrm{g} \mathrm{kg}^{-1}$ & $\mathrm{~g} \mathrm{~kg}^{-1}$ & $\mu g^{-1}$ d.m. & $\%$ & $\mu \mathrm{g}$ TPF $\mathrm{g}^{-1}$ d.m. $\mathrm{h}^{-1}$ & $\begin{array}{c}\mu \mathrm{g} \mathrm{CO} \mathrm{CO}_{2}-\mathrm{C} \\
\mathrm{g}^{-1} \text { d.m. } \mathrm{h}^{-1}\end{array}$ & $\begin{array}{c}\mu \mathrm{g} \mathrm{CO}_{2}-\mathrm{C} \mathrm{mg}^{-1} \\
\mathrm{C}_{\text {mic }} \mathrm{g}^{-1} \text { d.m. } \mathrm{h}^{-1}\end{array}$ \\
\hline \multirow[t]{2}{*}{ Cup plant } & EM & $\begin{array}{c}20.89 \\
( \pm 1.62)\end{array}$ & $\begin{array}{c}1.44 \\
( \pm 0.07)\end{array}$ & $\begin{array}{c}249.0 \\
( \pm 35.9)\end{array}$ & $\begin{array}{c}1.20 \\
( \pm 0.26)\end{array}$ & $\begin{array}{c}220.8 * \\
( \pm 111.1)\end{array}$ & $\begin{array}{l}3.00 * * \\
( \pm 0.55)\end{array}$ & $\begin{array}{c}11.53 * * * \\
( \pm 1.14)\end{array}$ \\
\hline & NM & $\begin{array}{c}19.80 \\
( \pm 0.22)\end{array}$ & $\begin{array}{c}1.43 \\
( \pm 0.02)\end{array}$ & $\begin{array}{c}203.4 \\
( \pm 26.9)\end{array}$ & $\begin{array}{c}0.95 \\
( \pm 0.07)\end{array}$ & $\begin{array}{c}53.0 \\
( \pm 23.8)\end{array}$ & $\begin{array}{c}1.23 \\
( \pm 0.05)\end{array}$ & $\begin{array}{c}6.17 \\
( \pm 0.81)\end{array}$ \\
\hline \multirow{2}{*}{$\begin{array}{l}\text { Jerusalem } \\
\text { artichoke }\end{array}$} & EM & $\begin{array}{c}18.49 \\
( \pm 0.90)\end{array}$ & $\begin{array}{c}1.40 \\
( \pm 0.04)\end{array}$ & $\begin{array}{l}187.8^{*} \\
( \pm 41.0)\end{array}$ & $\begin{array}{c}1.01 \text { * } \\
( \pm 0.22)\end{array}$ & $\begin{array}{c}98.5^{*} \\
( \pm 61.6)\end{array}$ & $\begin{array}{c}1.52 * \\
( \pm 0.75)\end{array}$ & $\begin{array}{c}8.37^{\circ} \\
( \pm 4.10)\end{array}$ \\
\hline & NM & $\begin{array}{c}19.28 \\
( \pm 0.40)\end{array}$ & $\begin{array}{c}1.46 * \\
( \pm 0.04)\end{array}$ & $\begin{array}{c}116.9 \\
( \pm 31.5)\end{array}$ & $\begin{array}{c}0.61 \\
( \pm 0.16)\end{array}$ & $\begin{array}{c}11.8 \\
( \pm 10.6)\end{array}$ & $\begin{array}{c}0.39 \\
( \pm 0.29)\end{array}$ & $\begin{array}{c}3.11 \\
( \pm 1.97) \\
\end{array}$ \\
\hline \multirow[t]{2}{*}{ Giant knotweed } & EM & $\begin{array}{l}20.23 \text { * } \\
( \pm 0.81)\end{array}$ & $\begin{array}{c}1.49 \\
( \pm 0.05)\end{array}$ & $\begin{array}{c}238.0 \\
( \pm 62.9)\end{array}$ & $\begin{array}{c}1.18 \\
( \pm 0.30)\end{array}$ & $\begin{array}{c}71.0 \\
( \pm 8.3)\end{array}$ & $\begin{array}{l}1.43^{* * *} \\
( \pm 0.14)\end{array}$ & $\begin{array}{c}6.72 * * \\
( \pm 1.31)\end{array}$ \\
\hline & NM & $\begin{array}{c}18.95 \\
( \pm 0.74)\end{array}$ & $\begin{array}{c}1.55 \\
( \pm 0.10)\end{array}$ & $\begin{array}{c}253.5 \\
( \pm 73.7)\end{array}$ & $\begin{array}{c}1.23 \\
( \pm 0.39)\end{array}$ & $\begin{array}{c}74.2 \\
( \pm 40.7) \\
\end{array}$ & $\begin{array}{c}0.76 \\
( \pm 0.14)\end{array}$ & $\begin{array}{c}3.20 \\
( \pm 1.03) \\
\end{array}$ \\
\hline \multirow[t]{2}{*}{ Tall wheatgrass } & EM & $\begin{array}{c}18.67 \\
( \pm 0.48)\end{array}$ & $\begin{array}{c}1.39 \\
( \pm 0.06)\end{array}$ & $\begin{array}{c}226.1 \\
( \pm 34.1) \\
\end{array}$ & $\begin{array}{c}1.18 \\
( \pm 0.21)\end{array}$ & $\begin{array}{c}44.4 \\
( \pm 36.7) \\
\end{array}$ & $\begin{array}{c}1.60 \text { * } \\
( \pm 0.52)\end{array}$ & $\begin{array}{r}6.94^{* *} \\
( \pm 1.45) \\
\end{array}$ \\
\hline & NM & $\begin{array}{c}19.11 \\
( \pm 0.62) \\
\end{array}$ & $\begin{array}{c}1.51^{\circ} \\
( \pm 0.09) \\
\end{array}$ & $\begin{array}{c}249.8 \\
( \pm 45.2) \\
\end{array}$ & $\begin{array}{c}1.31 \\
( \pm 0.25) \\
\end{array}$ & $\begin{array}{c}13.2 \\
( \pm 11.8) \\
\end{array}$ & $\begin{array}{c}0.60 \\
( \pm 0.10) \\
\end{array}$ & $\begin{array}{c}2.44 \\
( \pm 0.47) \\
\end{array}$ \\
\hline \multirow{2}{*}{$\begin{array}{l}\text { Reed canary } \\
\text { grass }\end{array}$} & EM & $\begin{array}{c}19.13 \\
( \pm 1.39)\end{array}$ & $\begin{array}{c}1.43 \\
( \pm 0.08)\end{array}$ & $\begin{array}{c}175.2 \\
( \pm 84.8)\end{array}$ & $\begin{array}{c}0.94 \\
( \pm 0.49)\end{array}$ & $\begin{array}{c}42.5 \\
( \pm 21.7)\end{array}$ & $\begin{array}{c}1.95 \text { ** } \\
( \pm 0.62)\end{array}$ & $\begin{array}{c}9.84 * \\
( \pm 2.30)\end{array}$ \\
\hline & NM & $\begin{array}{c}20.59 \\
( \pm 2.42)\end{array}$ & $\begin{array}{c}1.52 \\
( \pm 0.14)\end{array}$ & $\begin{array}{c}250.30 \\
( \pm 45.25)\end{array}$ & $\begin{array}{c}1.27 \\
( \pm 0.29)\end{array}$ & $\begin{array}{c}25.28 \\
( \pm 5.55)\end{array}$ & $\begin{array}{c}0.74 \\
( \pm 0.51)\end{array}$ & $\begin{array}{c}2.82 \\
( \pm 1.95)\end{array}$ \\
\hline
\end{tabular}




\section{Discussion}

Associated with waterlogged conditions during the winter half year, we observed positive responses of all PECs regarding growth parameters and could not observe negative impacts, although some of the PECs like the cup plant $[40,41]$ and tall wheatgrass [42] are described to be particularly drought resistant. However, there is no general consensus about the most favorable soil characteristics of several PECs. Assefa et al., Bittmann et al., Küppers-Sonnenberg, and USDA described the adaptation or tolerance against poorly drained soils for the cup plant, Jerusalem artichoke, tall wheatgrass and reed canary grass, respectively [43-46]. From a morphological perspective, hollow stems and large, soft leaf blades with a thin cuticle-layer indicate an adaptation of the mentioned PECs to rather moist habitats, which is also in line with their natural habitats. Areas that are characterized by high soil moisture contents like valleys, river banks, riparian zones and floodplains depict the natural habitat of the cup plant [47-50], giant knotweed [51,52] and reed canary grass [19,53]. Furthermore, it can be assumed that, depending on their provenance, specific ecotypes have developed which show different degrees of tolerability against waterlogging [54]. The good tolerability of the PECs against periodic waterlogging was reflected in significantly higher biomass yields in the EM compared to the NM treatment. Thus, the NM treatment appeared to provide less than optimum water supply conditions particularly for those species that showed significantly better WUEs in the EM than in the NM treatment (cup plant, Jerusalem artichoke, and reed canary grass). The NM conditions appeared to significantly restrict transpiration and biomass development. Similar observations were made by $[18,55]$ who determined comparably low WUEs of the cup plant and concluded the need of a high water supply to attain high yields. The similar WUEs of tall wheatgrass and giant knotweed in both soil moisture treatments indicate that these species can better cope with drier soil conditions which is in line with the morphological features of tall wheatgrass [42] and the wide ecological amplitude of Fallopia spp. [56,57].

\subsection{Plant Strategies to Avoid Anaerobic Stress and Effects on Soil Microbial Activity}

Thriving survival on sites that are periodically waterlogged depicts a challenge for plants and requires specific eco-physiological adaptation mechanisms [21-24]. Oxygen-depleted soil conditions would rapidly result in root hypoxia and accumulation of plant toxic substances followed by irreversible cell damages. Specific adaptation mechanisms were in sensu stricto not investigated for the PECs used in this experiment. However, a couple of widely known morphological and physiological strategies that allow plants to sustain waterlogged conditions are described in the literature and presumably also apply for the PECs used in this experiment. As described by [58] these adaptation mechanisms have a great implication for soil chemical properties and affect the habitat and activity of soil microorganisms. The results of root biomass and distribution in the pots also imply morphological adaptations of the PECs to stagnant water. The total root biomass showed significant differences among plant species and was in general higher in the upper half of the pot, likely resulting from fertilizer application and watering on the soil surface. Comparing the root distribution between the top and bottom layer of a certain species revealed that the roots of the cup plant and reed canary grass showed more intense rooting in the bottom layer of the EM compared to the NM treatment. In contrast to that, the root distribution of tall wheatgrass, giant knotweed, and the Jerusalem artichoke may either indicate a slight avoidance ('escape mechanism', [22] p. 8) or increased dying back and rotting of roots in the layer of stagnant water.

Aerenchyma tissue, formed either during normal plant development or as a response to transient hypoxic stress by numerous non-wetland species, allows for unimpeded gas diffusion between areas of low (roots) and high (shoots) oxygen concentration. Moreover, aerenchyma tissue serves as pathway for removal and detoxifying of phytotoxic substances formed (i) during anaerobic root metabolism like ethylene and (ii) under hypoxic rhizosphere conditions such as carbon dioxide and methane [21-23,59]. Although aerenchyma tissue primarily serves to avoid oxygen shortage and to maintain aerobic energy metabolism of roots, direct implications for the rhizosphere were documented. Bodelier stated 
that "roots also lose substantial amounts of oxygen to the surrounding anoxic soil" thereby leading to an active oxygenation of the rhizosphere [58]. The quantity of oxygen lost to the rhizosphere depends on photosynthetic activity of the plant due to the fact that substantial shares are descended from photosynthesis. However, Armstrong estimated that up to $40 \%$ of the oxygen supplied to the roots is lost during transport [60]. Wetland species lose substantially less oxygen due to their ability to form impermeable layers in the root walls $[22,58]$. High respiration rates and DHA in the EM treatments suggest that the PECs used in this experiment do not show this ability. Moreover, during washing out of the roots, we observed that the fine roots of the plants were coated with a layer that appeared like oxidized iron. Considering the high root density and the notable SOC increase in this pot experiment suggests that a predominant portion of the soil is addressed as root-influenced. Against this background, rhizosphere anoxia is thus not to be expected despite waterlogging during times in which plants are photosynthetically active. Indeed, improved soil microbial habitat conditions and microbial activity indicators such as higher DHA and soil respiration in the EM compared to the NM treatments may result from two processes. Firstly, aerenchyma tissue may only be formed in the plants of the EM treatment after sensing hypoxia leading to higher tissue porosity $[21,60,61]$ and thus a much better gas exchange between shoots and roots than in the NM treatment. Additionally, via the interior pathway, oxygen enriched air diffuses to the roots during times of photosynthetic activity whereas the atmosphere-to-soil pathway only allows diffusion of ambient air [22]. Secondly, in case of oxygen deprivation, fermentation processes gradually replace respiration. Fermentation inevitably comes along with cytotoxic metabolites and leads to an acidification of the cytoplasm [59]. However, Brimecombe et al. observed that a "decrease in oxygen concentration increases permeability of the cell membrane, ( ... ), resulting in increased exudation" [62]. Neumann et al. further specified that under hypoxic conditions, the exudation of sugars and amino acids is commonly increased and that fermentation products such as lactic acid and ethanol are released by some plant species [63]. Both processes are likely to stimulate aerobic heterotrophic microbial activity in the EM treatment; in general, priming of microbial activity by rhizodeposition is more pronounced for perennial species resulting from much higher amounts of carbon released compared to annual species [62]. However, increased respiration, which expresses in elevated metabolic quotients $\left(\mathrm{qCO}_{2}\right)$ indicates changes in the metabolic activity of the microbial community in the EM treatment, whereas the effects of plant species were generally of minor importance. The DHA was usually higher in the EM than in the NM treatment. Elevated DHA levels in the EM treatment can be explained by (i) the necessity of alcohol and lactate dehydrogenase for degradation of fermentation end products and (ii) a general increase in DHA with soil moisture as well as drying and rewetting cycles by the fact that DHA controls electron transfer in soil [64-68].

Active oxygen release by roots is an effective mechanism to avoid hypoxia only during photosynthetic active times. Against this background, carbohydrate reserves are essential to sustain energy metabolism during times in which cellular respiration exceeds the photosynthetic rate, due to significantly lower energy yields of fermentation ( 2 mol ATP per mol glucose) compared to respiration (32 mol ATP per mol glucose) [22]. Indeed, all PECs of this experiment exhibited rhizomes or tuberous roots as overwintering organs for carbohydrates and storage proteins $[42,49,53,56,69]$. Jackson et al. described this adaptation as "passive tolerance" to "survive winter anaerobiosis" [22]. Oxygen demand of roots and rhizosphere microorganisms to sustain aerobic energy metabolism is subjected to intense diurnal and seasonal changes. Resulting from significantly lower metabolic activity and associated oxygen demand of roots and rhizosphere microbes at lower temperatures, oxygen depletion and accumulation of cytotoxic fermentation end-products as well as cytoplasmic acidosis proceeds distinctly slower. Furthermore, the solubility of gases in water increases with lower temperatures. Moreover, Jackson et al. summarized modified gene expression that induces metabolic acclimation after sensing transient hypoxic conditions which may lead to elevated DHA and thus a higher level of anaerobic energy metabolism to sustain energy (ATP) supply. 


\subsection{Implications and Prospects for Field Conditions}

Summarizing, the good tolerance against waterlogged conditions and the conversion of high water availability in shoot biomass as observed for the PECs included in this study can certainly be traced back to their natural habitat. The presumed morphological and metabolic adaptations to avoid anoxia also affected rhizosphere processes. The much higher shoot biomass development in the EM treatment would certainly be relativized under field conditions-a typical limitation of pot experiments. Methodologically based, the soil water resource in the pots could not be exhausted by the plants resulting from continuous refilling to maintain the nominal soil moisture content. Under field conditions, it appears likely that plant available soil water content declined faster as a result of plant uptake. In this context, the large differences in biomass yields between the EM and the NM treatments observed in this experiment would certainly shrink. However, the magnitude of the effect on plants resulting from waterlogging shows dependencies from several biotic (e.g., morphologic adaptation mechanisms, metabolic acclimation, growth stage) and abiotic factors. Especially different abiotic conditions, compared to those tested in the framework of this experiment, like long-lasting waterlogging at higher temperatures, or even flooding, are likely to have adverse effects on plants [22,23]. Therefore, the outcomes of this experiment are to a certain extent methodologically determined and should be regarded as an initial step towards evaluating PECs to be grown on soils that show periodic waterlogging.

In this context, the specific soil conditions play a crucial role. In fact, the depth of the layer with low permeability decides upon the survival of the plants and the potential amount of soil water resource. Thus, in practice, particular attention should be paid to the site-specific soil conditions for successful cultivation of PECs on Stagnosols and Planosols. Indeed, it appears quite likely that a sharp, species-specific boundary between advantageous and disadvantageous levels of waterlogging below the ground surface exists. This particularly holds for the period of crop establishment when plants are typically more susceptible to waterlogging [23,29]. Considering that major portions of the root system of PECs are renewed each year, as for example discussed by [18] for the cup plant, waterlogged conditions below the perennating rootstock zone may not have detrimental effects for the plant. In contrast, waterlogging in the upper $20 \mathrm{~cm}$ of the soil or even flooding may result in total loss of the crop. Currently, these uncertainties and the associated financial risk, which is much higher than for annual crops due to very expensive establishment, present a major impediment for cultivation of the PECs in agricultural practice on Stagnosols and Planosols. Nonetheless, from today's perspective, a careful recommendation of the suitability of PECs, particularly the cup plant, Jerusalem artichoke, and reed canary grass for cultivation on 'mild' Stagnosols can be stated.

\section{Conclusions}

Growing of the tested PECs Stagnosols and Planosols may support site-adapted cultivation strategies due to their capability to outlive periods of waterlogged conditions in the winter half year and prevalently positive effects on biomass development as observed in this first experiment. The fast sprouting and early shoot biomass development of PECs resulting from large soil water resources in spring, and thus no growth limitation due to drought stress, may be a key factor in substantially outperforming maize on sites with temporary waterlogging. Nonetheless, although plants were able to cope with waterlogging, likely due to morphological and metabolic adaptation, soil microbial parameters indicated profound changes in metabolic activity pattern. Whether this stimulus was induced by oxygen shortage or other factors could not be proven. The results highlight that plant adaptations against hypoxic conditions of root tissue, particularly aerenchyma formation, oxygen loss and excretion to the rhizosphere, primarily ensure plant survival. However, they also prime microbial activity; although the rhizosphere is commonly referred to as a competitive environment for oxygen. Thus, the results of this initial study also emphasized the need for pursuing research on the topic. Identification of susceptible crop stages and specific adaptation mechanisms, monitoring of oxygen saturation and redox potential and knowledge about the impact of different soil textures 
would be valuable to select the most appropriate PECs for specific site conditions. Moreover, field trials are essential to determine specific interactions of certain species with soil climatic conditions of Stagnosols and Planosols, like the slower warming up of water-saturated soils in spring or high-water vapor saturation of the boundary layer. With respect to the much earlier vegetation start of PECs, when Stagnosols and Planosols typically still show waterlogging, questions about suitable, climate-friendly ways of fertilization emerge.

Author Contributions: Conceptualization, T.R., and C.E.; investigation, T.R., V.A. and K.H.; methodology, T.R. and C.E.; project administration, T.R.; resources, T.R. and C.E.; software, T.R.; supervision, T.R. and C.E.; validation, T.R.; visualization, T.R.; writing—original draft, T.R.; writing—review and editing, T.R.

Funding: The scholarship foundation of the Federal State of Rhineland-Palatinate has granted a graduate scholarship for Thorsten Ruf to perform this project. The publication was funded by the Open Access Fund of Universität Trier and the German Research Foundation (DFG) within the Open Access Publishing funding program.

Acknowledgments: We kindly acknowledge Ramesh Sangumani for his support during the growing of plants. The technical staff of the soil science department, Elvira Sieberger and Petra Ziegler, are thanked for their valuable assistance. Carsten Eichberg and Stefan Schrader are kindly thanked for a pre-review and their valuable comments.

Conflicts of Interest: The authors declare no conflicts of interest.

\section{References}

1. Alexander, P.; Rounsevell, M.D.; Dislich, C.; Dodson, J.R.; Engström, K.; Moran, D. Drivers for global agricultural land use change: The nexus of diet, population, yield and bioenergy. Glob. Environ. Chang. 2015, 35, 138-147. [CrossRef]

2. Bowyer, C.; Kretschmer, B. Anticipated Indirect Land Use Change Associated with Expanded Use of Biofuels and Bioliquids in the EU-An Analysis of the National Renewable Energy Action Plans; Institute for European Environmental Policy: London, UK, 2011.

3. Von Cossel, M.; Möhring, J.; Kiesel, A.; Lewandowski, I. Optimization of specific methane yield prediction models for biogas crops based on lignocellulosic components using non-linear and crop-specific configurations. Ind. Crop. Prod. 2018, 120, 330-342. [CrossRef]

4. Haag, N.L.; Nägele, H.-J.; Reiss, K.; Biertümpfel, A.; Oechsner, H. Methane formation potential of cup plant (Silphium perfoliatum). Biomass Bioenergy 2015, 75, 126-133. [CrossRef]

5. Herrmann, A.; Rath, J. Biogas Production from Maize: Current State, Challenges, and Prospects. 1. Methane Yield Potential. BioEnergy Res. 2012, 5, 1027-1042. [CrossRef]

6. Mayer, F.; Gerin, P.A.; Noo, A.; Lemaigre, S.; Stilmant, D.; Schmit, T.; Leclech, N.; Ruelle, L.; Gennen, J.; Von Francken-Welz, H.; et al. Assessment of energy crops alternative to maize for biogas production in the Greater Region. Bioresour. Technol. 2014, 166, 358-367. [CrossRef] [PubMed]

7. Oslaj, M.; Muršec, B.; Vindis, P. Biogas production from maize hybrids. Biomass Bioenergy 2010, 34, $1538-1545$. [CrossRef]

8. Seppälä, M.; Laine, A.; Rintala, J. Screening of novel plants for biogas production in northern conditions. Bioresour. Technol. 2013, 139, 355-362. [CrossRef]

9. Acharya, B.S.; Blanco-Canqui, H. Lignocellulosic-based bioenergy and water quality parameters: A review. Glob. Chang. Biol. Bioenergy 2018, 10, 504-533. [CrossRef]

10. Blanco-Canqui, H. Energy Crops and Their Implications on Soil and Environment. Agron. J. 2010, $102,403$. [CrossRef]

11. Chimento, C.; Almagro, M.; Amaducci, S. Carbon sequestration potential in perennial bioenergy crops: The importance of organic matter inputs and its physical protection. Glob. Chang. Biol. Bioenergy 2016, 8, 111-121. [CrossRef]

12. Haughton, A.J.; Bohan, D.A.; Clark, S.J.; Mallott, M.D.; Mallott, V.; Sage, R.; Karp, A. Dedicated biomass crops can enhance biodiversity in the arable landscape. Glob. Chang. Biol. Bioenergy 2016, 8, 1071-1081. [CrossRef] [PubMed]

13. Kort, J.; Collins, M.; Ditsch, D. A review of soil erosion potential associated with biomass crops. Biomass Bioenergy 1998, 14, 351-359. [CrossRef] 
14. Landis, D.A.; Gratton, C.; Jackson, R.D.; Gross, K.L.; Duncan, D.S.; Liang, C.; Meehan, T.D.; Robertson, B.A.; Schmidt, T.M.; Stahlheber, K.A.; et al. Biomass and biofuel crop effects on biodiversity and ecosystem services in the North Central US. Biomass Bioenergy 2018, 114, 18-29. [CrossRef]

15. Ruf, T.; Makselon, J.; Udelhoven, T.; Emmerling, C.; Ruf, T.; Udelhoven, T. Soil quality indicator response to land-use change from annual to perennial bioenergy cropping systems in Germany. GCB Bioenergy 2018, 10, 444-459. [CrossRef]

16. Dickeduisberg, M.; Laser, H.; Tonn, B.; Isselstein, J. Tall wheatgrass (Agropyron elongatum) for biogas production: Crop management more important for biomass and methane yield than grass provenance. Ind. Crop. Prod. 2017, 97, 653-663. [CrossRef]

17. Batey, T. Soil compaction and soil management-A review. Soil Use Manag. 2009, 25, 335-345. [CrossRef]

18. Schoo, B.; Schroetter, S.; Kage, H.; Schittenhelm, S. Root traits of cup plant, maize and lucerne grass grown under different soil and soil moisture conditions. J. Agron. Crop Sci. 2017, 203, 345-359. [CrossRef]

19. Lewandowski, I.; Scurlock, J.M.; Lindvall, E.; Christou, M. The development and current status of perennial rhizomatous grasses as energy crops in the US and Europe. Biomass Bioenergy 2003, 25, 335-361. [CrossRef]

20. Venendaal, R.; Jørgensen, U.; Foster, C.A. European energy crops: A synthesis. Biomass Bioenergy 1997, 13, 147-185. [CrossRef]

21. Evans, D.E. Aerenchyma formation. New Phytol. 2003, 161, 35-49. [CrossRef]

22. Jackson, M.B.; Vartapetian, B.B. Plant Adaptations to Anaerobic Stress. Ann. Bot. 1997, 79, 3-20.

23. Gregory, P. Plant Roots: Their Growth, Activity, and Interaction with Soils; Blackwell Publishing: Oxford, UK, 2006.

24. Verhoef, A.; Egea, G. Soil water and its management. In Soil Conditions and Plant Growth; Gregory, P.J., Nortcliff, S., Eds.; Blackwell Publishing: Oxford, UK, 2013; pp. 269-322.

25. Peel, M.C.; Finlayson, B.L.; McMahon, T.A. Updated world map of the Köppen-Geiger climate classification. Hydrol. Earth Syst. Sci. 2007, 11, 1633-1644. [CrossRef]

26. Ad-hoc-AG, B. Bodenkundliche Kartieranleitung. 5; Schweizerbart'sche Verlagsbuchhandlung: Berlin, Germany, 2005.

27. FAO. World Reference Base for Soil Resources 2014: International Soil Classification System for Naming Soils and Creating Legends for Soil Maps; Update 2015; World Soil Resources Reports; FAO: Rome, Italy, 2015.

28. FAO. Guidelines for Soil Description, 4th ed.; FAO: Rome, Italy, 2006.

29. Zaidi, P.H.; Rafique, S.; Rai, P.; Singh, N.; Srinivasan, G. Tolerance to excess moisture in maize (Zea mays L.): Susceptible crop stages and identification of tolerant genotypes. Field Crop. Res. 2004, 90, 189-202. [CrossRef]

30. Hallett, P.D.; Bengough, A.G. Managing the soil physical environment for plants. In Soil Conditions and Plant Growth, 12th ed.; Gregory, P.J., Nortcliff, S., Eds.; Blackwell Publishing: Ames, IA, USA, 2013; pp. 238-268.

31. Richards, L.A.; Fireman, M. Pressure-Plate Apparatus for Measuring Moisture Sorption and Transmission by Soils. Soil Sci. 1943, 56, 395-404. [CrossRef]

32. Kohn, M. Bemerkungen zur mechanischen Bodenanalyse IV. J. Plant Nutr. Soil Sci. 1929, 14, $268-280$. [CrossRef]

33. Vance, E.; Brookes, P.; Jenkinson, D. An extraction method for measuring soil microbial biomass C. Soil Boil. Biochem. 1987, 19, 703-707. [CrossRef]

34. Joergensen, R.G. The fumigation-extraction method to estimate soil microbial biomass: Calibration of the kEC value. Soil Boil. Biochem. 1996, 28, 25-31. [CrossRef]

35. Isermeyer, H. Eine einfache Methode zur Bestimmung der Bodenatmung und der Karbonate in Böden. Z. Für Pflanz. Düngung Und Bodenkd. 1952, 56, 26-38. [CrossRef]

36. Alef, K. Soil respiration. In Methods in Applied Soil Microbiology and Biochemistry; Alef, K., Nannipieri, P., Eds.; Academic Press: London, UK, 1995; pp. 214-222.

37. Thalmann, A. Zur Methodik der Bestimmung der Dehydrogenaseaktivität im Boden mittels Triphenyltetrazoliumchlorid (TTC). Landwirtsch. Forsch. 1968, 21, 249-258.

38. Dunger, W.; Fiedler, H.J. Methoden der Bodenbiologie; Gustav Fischer Verlag: Stuttgart, Germany, 1997.

39. R Core Team. R: A Language and Environment for Statistical Computing; R Foundation for Statistical Computing: Vienna, Austria, 2016.

40. Bauböck, R.; Karpenstein-Machan, M.; Kappas, M. Computing the biomass potentials for maize and two alternative energy crops, triticale and cup plant (Silphium perfoliatum L.), with the crop model BioSTAR in the region of Hannover (Germany). Environ. Sci. Eur. 2014, 26, 19. [CrossRef] 
41. Franzaring, J.; Schmid, I.; Bäuerle, L.; Gensheimer, G.; Fangmeier, A. Investigations on the plant functional traits, epidermal structures and the ecophysiology of the novel bioenergy species Sida hermaphrodita Rusby and Silphium perfoliatum L. J. App. Bot. Food Qual. 2014, 87, 36-45.

42. Csete, S. Tall Wheatgrass Cultivar Szarvasi-1 (Elymus elongatus subsp. ponticus cv. Szarvasi-1) as a Potential Energy Crop for Semi-Arid Lands of Eastern Europe. In Sustainable Growth and Applications in Renewable Energy Sources; Nayeripour, M., Kheshti, M., Eds.; Intech: Dublin, Ireland, 2011; pp. 269-294.

43. Assefa, T.; Wu, J.; Albrecht, K.A.; Johnson, P.J.; Boe, A. Genetic Variation for Biomass and Related Morphological Traits in Cup Plant (Silphium perfoliatum L.). Am. J. Plant Sci. 2015, 6, 1098-1108. [CrossRef]

44. Bittman, S.; Waddington, J.; Coulman, B.E.; Bonin, S.G. Reed Canarygrass: A Production Guide; Publication Agriculture: Ottawa, ON, Canada, 1980.

45. Küppers-Sonnenberg, G.A. Topinambur. Anbau und Nutzungsmöglichkeit. Das Wissenswerte aus Theorie und Praxis; Landbuch-Verlag: Hannover, Germany, 1947.

46. USDA. Plant Guide Tall Wheatgrass Thinopyrum ponticum (Podp.); Liu, Z.-W., Wang, R.-C., Eds.; United States Department for Agriculture Natural Resources Conservation Service USDA NRCS, National Plant Data Center: Oakland, CA, USA, 2008. Available online: https://www.plants.usda.gov/plantguide/pdf/pg_thpo7.pdf (accessed on 4 September 2018).

47. Sokolov, V.S.; Gritsak, Z.I. Silphium-A valuable fodder and nectariferous crop. World Crop. 1972, 24, 299-301.

48. Stanford, G. Silphium perfoliatum (cup-plant) as a new forage. In Recapturing a Vanishing Heritage, Proceedings of the12th North American Prairie Conference; University of Northern Iowa: Cedar Falls, IA, USA, 1990; pp. 33-38.

49. USDA. Plant Guide Cup Plant Silphium perfoliatum L.; United States Department for Agriculture Natural Resources Conservation Service USDA NRCS, National Plant Data Center: Oakland, CA, USA, 2002. Available online: http://plants.usda.gov/plantguide/pdf/cs_sipe2.pdf (accessed on 4 September 2018).

50. Vacek, V.; Repka, R. Concise results of the experiment with Silphium perfoliatum L. Plant Genet. Res. Charact. Util. 1992, 5-13.

51. Gerber, E.; Krebs, C.; Murrell, C.; Moretti, M.; Rocklin, R.; Schaffner, U. Exotic invasive knotweeds (Fallopia spp.) negatively affect native plant and invertebrate assemblages in European riparian habitats. Boil. Conserv. 2008, 141, 646-654. [CrossRef]

52. Patfield, D.; Boiché, A.; Riipinen, M.P.; Dobson, M.; Lecerf, A.; Chauvet, E. Stream ecosystems respond to riparian invasion by Japanese knotweed (Fallopia japonica). Can. J. Fish. Aquat. Sci. 2007, 64, 1273-1283.

53. USDA. Plant Guide Reed Canarygrass Phalaris arundinacea L.; United States Department for Agriculture Natural Resources Conservation Service USDA NRCS, National Plant Data Center: Oakland, CA, USA, 2002. Available online: https://plants.usda.gov/plantguide/pdf/pg_phar3.pdf (accessed on 4 September 2018).

54. Lindvall, E. Breeding reed canarygrass as an energy or fibre crop. Potential yield capacity and variation in quality characters in locally collected ecotypes. In Proceedings of the 20th Meeting of the Eucarpia Fodder Crops and Amenity Grasses Section, Radzikow, Poland, 7-10 October 1996; pp. 117-120.

55. Schoo, B.; Wittich, K.P.; Böttcher, U.; Kage, H.; Schittenhelm, S. Drought tolerance and water-use efficiency of biogas crops: A comparision of cup plant, maize and lucerne-grass. J. Agron. Crop Sci. 2017, 203, 117-130. [CrossRef]

56. Forman, J.; Kesseli, R.V. Sexual reproduction in the invasive species Fallopia japonica (Polygonaceae). Am. J. Bot. 2003, 90, 586-592. [CrossRef]

57. Michigan Department of Natural Resources. Japanese Knotweed (Fallopia japonica). Invasive Species: Best Control Practices. 2012. Available online: https://www.michigan.gov/documents/dnr/knotweed_BCP_ 372280_7.pdf (accessed on 30 December 2018).

58. Bodelier, P.L.E. Interactions between oxygen-releasing roots and microbial processes in flooded soils and sediments. In Root Ecology. Ecological Studies 168; de Kroon, H., Visser, E.J.W., Eds.; Springer: Berlin/Heidelberg, Germany, 2003; pp. 331-362.

59. Jackson, M.B.; Ricard, B. Physiology, biochemistry and molecular biology of plant root systems subjected to flooding of the soil. In Root Ecology. Ecological Studies 168; de Kroon, H., Visser, E.J.W., Eds.; Springer: Berlin/Heidelberg, Germany, 2003; pp. 193-213.

60. Armstrong, W. Aeration in higher plants. Adv. Bot. Res. 1979, 7, $225-332$.

61. Colmer, T.D. Long-distance transport of gases in plants: A perspective on internal aeration and radial oxygen loss from roots. Plant Cell Environ. 2003, 26, 17-36. [CrossRef] 
62. Brimecombe, M.J.; De Leij, F.A.A.M.; Lynch, J.M. Rhizodeposition and microbial populations. In The Rhizosphere: Biochemistry and Organic Substances at the Soil-Plant Interface; Pinton, R., Varanini, Z., Nannipieri, P., Eds.; CRC Press: Boca Raton, FL, USA, 2007; pp. 73-110.

63. Neumann, G.; Römheld, V. The release of root exudates as affected by the plant physiological status. In The Rhizosphere: Biochemistry and Organic Substances at the Soil-Plant Interface; Pinton, R., Varanini, Z., Nannipieri, P., Eds.; CRC Press: Boca Raton, FL, USA, 2007; pp. 23-72.

64. Gu, Y.; Wang, P.; Kong, C. Urease, invertase, dehydrogenase and polyphenoloxidase activities in paddy soil influenced by allelopathic rice variety. Eur. J. Soil Boil. 2009, 45, 436-441. [CrossRef]

65. Weaver, M.A.; Zablotowicz, R.M.; Krutz, L.J.; Bryson, C.T.; Locke, M.A. Microbial and vegetative changes associated with development of a constructed wetland. Ecol. Indic. 2012, 13, 37-45. [CrossRef]

66. Zhao, B.; Chen, J.; Zhang, J.; Qin, S. Soil microbial biomass and activity response to repeated drying-rewetting cycles along with a soil fertility gradient modified by long-term fertilization management practices. Geoderma 2010, 160, 218-224. [CrossRef]

67. Wignarajah, K.; Greenway, H.; John, C.D. Effects of waterlogging on growth and activity of alcohol dehydrogenase in barley and rice. New Phytol. 1976, 77, 585-592. [CrossRef]

68. Wolinska, A.; Stępniewska, Z. Microorganisms abundance and dehydrogenase activity as a consequence of soil reoxidation process. In Soil Tillage and Microbial Activities; Miransari, M., Ed.; Research Signpost: Kerala, India, 2011; pp. 111-143.

69. Kosaric, N.; Cosentino, G.P.; Wieczorek, A.; Duvnjak, Z. The Jerusalem Artichoke as an Agricultural Crop. Biomass 1984, 5, 1-36. [CrossRef]

(C) 2019 by the authors. Licensee MDPI, Basel, Switzerland. This article is an open access article distributed under the terms and conditions of the Creative Commons Attribution (CC BY) license (http://creativecommons.org/licenses/by/4.0/). 